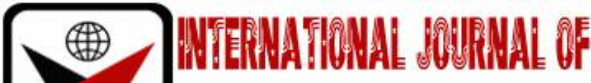

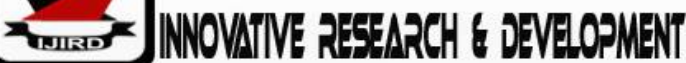

ISSN 2278-0211 (Online)

\section{Practitioner Validation toward Instructional Design Model Based on Contextual Teaching and Learning (CTL) for English Writing Skill}

Yulia, Muhammad Rusdi
Student, Department of Postgraduate Education Doctoral Program,
Jambi University, Indonesia
Saharudin
Lecturer, Department of Postgraduate Education Doctoral Program,
Jambi University, Indonesia

\section{Abstract:}

This article is one part of design and development research with the title 'instructional design model based on contextual teaching and learning (CTL) for English writing skill.' After validation by design and subject matter expert, practitioners (English teachers) were tested for use design model as a guide on designing instructional lesson plan. Practitioners consist of two parts from different English teacher association. This external validation aimed to get information or data about easiness, clearness of design model that has developed in giving guidance for English teacher on designing instructional lesson plan. The result of practitioner trial reveal that qualities of lesson plan before and after using the design model was improved. The practitioner capable on designing instructional lesson plan based on principles and approaches of contextual teaching and learning.

Keywords: Practitioner validation, instructional design model, contextual teaching and learning (CTL)

\section{Introduction}

Learning English in Indonesia was obtained through instructional process. It need some efford to be mastered. The internal efford is a kind of students' to be mastered English on learning process, meanwhile external process is outside of students, it comes from teacher's efford in instructional process in order to make students master in English. The curriculum that is use in Indonesia is called curriculum 2013. This curriculum was designed to carry out of $21^{\text {st }}$ century learning.

Contextual teaching and learning is one of instructional model and approach of $21^{\text {st }}$ century learning. Using Contextual teaching and learning on learning process can help students mastering English easly because of material choice appropriate with students real life. Johnson (2002) defined that CTL as an instructional process that aimed to help students' meaningfull understanding on learning process which is conected material with students' daily activities, personality, social, and culture.

The reseach was design and development which a product finding instructional design model based on contextual teaching and learning (CTL) for English writing skill. The practitioner try out of product in order to get information or data about easiness,clearness of design model that has developed in giving guidance for english teacher on designing instructional lesson plan.

\section{Research Methodology}

Lee \& Jang (2014) stated that review toward instructional design model can be done by practitioner in order to get practitioner's opinion. The pactitioner trial scenario as follows: 1) researcher chose 5 English teachers as participant. 2) reseacher explainedthat the aimed of trial. 3) reseacher explained that participant will make instructional design based on contextual teaching and learning for english writing skill. 4) reseacher explained that participant should follow guidance of instructional desain model which has developed. 5) next, researcher explained what is instructional design model and component which has developed. 6) researcher give opportunities and time for participant to understandthe concept and implemened it on lasson plan. 7) researcher asked some opinions and suggestions for making design product more better. 


\section{Data Collection}

\subsection{Kind of Data and Instrument for Collecting Data}

The kind of data in this study was qualitative. Qualitative data was obtained from practitioner review and trial of instructional design model through quistionnaires, interview, observation and document analysis toward practitioner's instructional lesson plan.

According to Richey \& Klein (2007) a tool of collecting data that use in design and development reseach was work log, surveys or questionnaires, protocol interviews. Rusdi (2018) stated that technique for collecting data qualitative through interview, observation, document analysis.

\section{Result}

\subsection{Questionnaires Result}

Questionnaires for practitioner conducted in order to get information about: 1) intrinsic aspect involves cleanliness, easiness of using the product, sequences, and also completeness of the elements in product. 2) impact aspect use the product ( Rusdi, 208). Here are some questions in the Questionnaires and practitioner's answers.

\begin{tabular}{|c|c|}
\hline No & Pertanyaan \\
\hline \multirow[t]{3}{*}{1} & 1. Do the phase of need analysis help you to: \\
\hline & 1.1 Identify English writing skill problem \\
\hline & $\begin{array}{l}\text { Answers: SW, DA, NA, LS, BM } \\
\text { The product can help me and easy to understand, also it give us quidence and example } \\
\text { in identifying writing skill problem }\end{array}$ \\
\hline \multirow[t]{7}{*}{2} & 2. Do the phase of students' characteristics analysis help you to: \\
\hline & 2.1 Analyze students' characteristics in general \\
\hline & $\begin{array}{l}\text { Answers: SW, DA, NA, LS, BM } \\
\text { Yes, it can help me toanalyze students' characteristics in general }\end{array}$ \\
\hline & 2.2 Analyze students' entry behavior or prerequisite skill for English writing skill \\
\hline & $\begin{array}{l}\text { Answers: SW, DA, NA, LS, BM } \\
\text { Yes, it can help me to analyze students' entry behavior or prerequisite skill for English } \\
\text { writing skill }\end{array}$ \\
\hline & 2.3 Analyze students' motivation in writing skill \\
\hline & $\begin{array}{l}\text { Answers: SW, DA, NA, LS, BM } \\
\text { Yes, it can help me to analyze students' motivation in writing skill }\end{array}$ \\
\hline \multirow[t]{5}{*}{3} & 3. Do the phase of analyzing learning context which describe in product help you to: \\
\hline & $\begin{array}{l}\text { 3.1 Comprehendwhat learning context based on contextual teaching and } \\
\text { learrning mean is }\end{array}$ \\
\hline & $\begin{array}{l}\text { Answers: SW, DA, NA, LS, BM } \\
\text { Yes, it can help me to comprehend what learning context based on contextual mean is }\end{array}$ \\
\hline & 3.2Comprehend how preparing in learning context based on contextual is \\
\hline & $\begin{array}{l}\text { Answers: SW, DA, NA, LS, BM } \\
\text { Yes, it can help metocomprehend how preparing in learning context based on } \\
\text { contextual is }\end{array}$ \\
\hline \multirow[t]{5}{*}{4} & 4. Do determine learning objectives which describe in the product help you to: \\
\hline & 4.1 comprehend what learning objectives mean is \\
\hline & 4.2 Identify learning objectives of cognitive, affective, and psychomotor domain \\
\hline & 4.3 How to formulate instructional objectives based on CTL \\
\hline & $\begin{array}{l}\text { Answers: SW, DA, NA, LS, BM } \\
\text { Yes, it can help me to understand about instructional objectives, how to identify } \\
\text { cognitives, affective, and psychomotor domain. It also help me in formulating } \\
\text { instructional objectives }\end{array}$ \\
\hline \multirow[t]{7}{*}{5} & $\begin{array}{l}\text { 5. Do the phase of determining instructional strategy based on CTL which describe in } \\
\text { the product help you to: }\end{array}$ \\
\hline & 5.1 Comprehend instructional approach based on CTL for writing skill \\
\hline & $\begin{array}{l}\text { Answers: SW, DA, NA, LS, BM } \\
\text { Yes, it can help me tocomprehend instructional approach based on CTL for writing } \\
\text { skill }\end{array}$ \\
\hline & 5.2 Comprehend authentic assessment \\
\hline & $\begin{array}{l}\text { Answers: SW, DA, NA, LS, BM } \\
\text { Yes, it can help me to comprehend authentic assessment }\end{array}$ \\
\hline & 5.3Comprehend instructional model and method based on CTL \\
\hline & $\begin{array}{l}\text { Answers: SW, DA, NA, LS, BM } \\
\text { Yes, it can help me tocomprehend instructional model and method based on CTL }\end{array}$ \\
\hline
\end{tabular}




\begin{tabular}{|c|c|}
\hline No & Pertanyaan \\
\hline \multirow[t]{11}{*}{6} & $\begin{array}{l}\text { 6. Do the phase of developing instructional material based on CTL which describe in } \\
\text { the product help you in: }\end{array}$ \\
\hline & 6.1 Comprehend what instructional material based on CTL mean is \\
\hline & $\begin{array}{l}\text { Answers: SW, DA, NA, LS, BM } \\
\text { Yes, it can help me toComprehend what instructional material based on CTL mean is }\end{array}$ \\
\hline & 6.2 memahami penggunaan pendekatan teks \\
\hline & $\begin{array}{l}\text { Answers: SW, DA, NA, LS, BM } \\
\text { Yes, it can help me tocomprehend how to use text driven }\end{array}$ \\
\hline & 6.3 Comprehend of developing authentic text \\
\hline & $\begin{array}{l}\text { Answers: SW, DA, NA, LS, BM } \\
\text { Yes, it can help me to comprehend of developing authentic text }\end{array}$ \\
\hline & 6.4 Comprehend procedure of developing instructional material \\
\hline & $\begin{array}{l}\text { Answers: SW, DA, NA, LS, BM } \\
\text { Yes, it can help me in comprehend procedure of developing instructional material }\end{array}$ \\
\hline & 6.5 Developing authentic test \\
\hline & $\begin{array}{l}\text { Answers: SW, DA, NA, LS, BM } \\
\text { Yes, it can help me to develop authentic test }\end{array}$ \\
\hline \multirow[t]{8}{*}{7} & $\begin{array}{l}\text { 7. Do the phase of media and instructional material delivery system which describe } \\
\text { in the product help you to: }\end{array}$ \\
\hline & 7.1 Comprehend instructional media \\
\hline & $\begin{array}{l}\text { Answers: SW, DA, NA, LS, BM } \\
\text { Yes, it help me to comprehend instructional media }\end{array}$ \\
\hline & 7.2 Comprehend commercial media usage \\
\hline & $\begin{array}{l}\text { Answers: SW, DA, NA, LS, BM } \\
\text { Yes, it help me Comprehend commercial media usage }\end{array}$ \\
\hline & 7.3 Developing instructional media \\
\hline & $\begin{array}{l}\text { Answers: SW, DA, NA, LS, BM } \\
\text { Yes, it help me to develop instructional media }\end{array}$ \\
\hline & 7.4 Comprehend in determining istructional material delivery system \\
\hline \multirow[t]{7}{*}{8} & 8. Do the phase of formative evaluation which describe in the product help you to \\
\hline & 8.1 Comprehend formative evaluation in design process \\
\hline & $\begin{array}{l}\text { Answers: SW, DA, NA, LS, BM } \\
\text { Yes, it help me to comprehend formative evaluation in design process }\end{array}$ \\
\hline & 8.1.1 Comprehend formative evaluation approach in design process \\
\hline & 8.2 Comprehend formative evaluation in instructional process \\
\hline & $\begin{array}{l}\text { Answers: SW, DA, NA, LS, BM } \\
\text { Yes, it help me to comprehend formative evaluation in instructional process }\end{array}$ \\
\hline & 8.2.1 Comprehend formative evaluation technique in instructional process \\
\hline \multirow[t]{2}{*}{9} & $\begin{array}{l}\text { 9. Do the phase of doing revision which describe in the product help you to } \\
\text { comprehend the purpose of revision in instruction design model }\end{array}$ \\
\hline & $\begin{array}{l}\text { Answers: SW, DA, NA, LS, BM } \\
\text { Yes, it help me to comprehend what intention of revision in instructional design model } \\
\text { is }\end{array}$ \\
\hline
\end{tabular}

\section{Table 1: Questionnaires Result}

Based on practitioners' answers, it can conclude that all phase on instructional design model based on CTL for English writing skill which developed are easy to understand and it to used and it help them how to design lesson plan based on CTL.

\subsection{Interview Result}

The interview in this study use to get information about description of componentinstructional design model based on CTL for English writing skill which was developed. Here are some protocol interviews and practitioners' answers: 


\begin{tabular}{|l|l|}
\hline No & \multicolumn{1}{|c|}{ Protocol Interviews } \\
\hline 1 & $\begin{array}{l}\text { According to you, do the description of each component which described are clear and } \\
\text { easy to undestand? }\end{array}$ \\
\hline 2 & According to you, do the examples in the product are are clear and easy to undestand? \\
\hline 3 & $\begin{array}{l}\text { According to you, do the pictures, letters and complexity in the product are are clear, } \\
\text { interesting and easy to undestand? }\end{array}$ \\
\hline 4 & $\begin{array}{l}\text { According to you, do the procedures and phases in using instructional design model } \\
\text { based on CTL for English writing skill which developed appropriate in instructional } \\
\text { designing ? }\end{array}$ \\
\hline 5 & $\begin{array}{l}\text { According to you, do procedures and phases miss in instructional design model based } \\
\text { on CTL for English writing skill which is not appropriated and need to be fixed? }\end{array}$ \\
\hline 6 & $\begin{array}{l}\text { According to you, do each procedures of instructional design model based on CTL for } \\
\text { English writing skill easy to follow? }\end{array}$ \\
\hline 7 & $\begin{array}{l}\text { According to you, do instructional design model based on CTL for English writing skill } \\
\text { which is developed can be used as guidance for you in designing instructional based on } \\
\text { CTL? }\end{array}$ \\
\hline
\end{tabular}

Table 2: Interview Result

From two group of practitioners that researcher interview stated that describtion of each components clear and easy to understand. Practitioners stated that all examples which are given in the product also clear and easy to understand. They also stated that pictures, letters and complexity of the product easy to understand, clear and the pictures were interesting, appropriate with students real life. The phases of instructional design model already appropriate for designing instructional. All participants stated that procedures instructional design model based on CTL which was developed nothing need to be fixed. They also said that all components are easy to followed. And at last they said that instruction design model which was developed can use as guidance for English teacher in designing instructional for writing skill. However, according to practitioners, because of product is thick so it can be more easy to understand if it is practical guidance.

\subsection{Observation Result}

Observation made to observe practitioners (teacher) in designing instructional based on CTL for English writing skill. The purpose of observation to get information about how practitioners plan and design instructional. Here are observational guidelines:

\begin{tabular}{|l|l|}
\hline No & \multicolumn{1}{|c|}{ Observation Guidelines } \\
\hline 1 & $\begin{array}{l}\text { The first activity that practitioners do in designing instructional model based on CTL } \\
\text { for English writing skill }\end{array}$ \\
\hline 2 & $\begin{array}{l}\text { Wheather practitioners make some instructional planning before designing } \\
\text { instructional lesson plan }\end{array}$ \\
\hline 3 & Wheather practitioners design instructional alone or they modify from other design \\
\hline 4 & $\begin{array}{l}\text { Wheather practitioners follow instructional model design based on CTL for English } \\
\text { writing or not }\end{array}$ \\
\hline 5 & $\begin{array}{l}\text { Wheather practitioners find some problems when they design instructional model } \\
\text { design based on CTL for English writing }\end{array}$ \\
\hline 6 & $\begin{array}{l}\text { What practitioners do when they find some problems in designing instructional based } \\
\text { on CTL for English writing skill }\end{array}$ \\
\hline
\end{tabular}

Table 3: Observation Result

Based on observational guidelines above can be explained as follow: The first observational guidelines found that all practitioners did first activity to identify core competency and basic competency and after that they determine indicators of competence achievement. Some of practitioners were not accustomed to determine indicators of competence achievement especially for choosing operational verbs based on taxonomy Bloom. For second observational guidelines, researcher found that all practitioners did some plan before they designed instructional but they never wrote down in formally. They actually though about media, students' task and evaluation which was appropriate with material chosen. For third observational guidelines, some of practitioner said that they did their own instructional design and some of them said that they just modify instructional designs which were available. Based on fourth observational guidelines, found that some of practitioner follow the procedure in designing instructional based on CTL but some of them did not. And for fifth and sixth observational guidelines, there is not found important problem and if they found some problem, they asked reseacher directly. 


\subsection{Document Analysis Result}

\subsubsection{The Result of Practitioners Lesson Plan Review before Knowing Instructional Design}

Review of Practitioners lesson plan was done to compare practitioner knowledge before and after using instructional design model based on CTL. In this phase, researcher did Practitioners lesson plan review in two group of participants. Researcher found that participants lesson plan review toward SW, DA, NA, LS, and BM before using instructional design model which was developed, the scores average 64.74 up to 67.64. It mean that lesson plan which practitioner designed were in the low category based on criteria of CTL instruction design.

\subsubsection{The Result of Practitioners Lesson Plan Review after Knowing Instructional Design}

Review of Practitioners lesson plan after using instructional design model based on CTL. In this phase, researcher asked Practitioners to make lesson plan in accordance with class being taught. The lesson plan will design based on basic competencies in the current semester or for the next semester. The practitioners' lesson plan focused on writing skill domain. Based on practitioners' lesson plan review toward SW, DA, NA, LS, and BM after using instructional design model which was developed, the scores average 91.17 up to 97.05 . It mean that lesson plan which practitioners designed were in the excellent category based on criteria of CTL instruction design.

\section{Conclusion}

External validation toward instructional design model based on CTL for English writing skill through questionnaires, observation, interview, and document analysis can be concluded that instructional design which was developed stated that the sequences and komponens of design complete. The product that was developed can be used as guidance in designing instructional based on CTL (lesson plan) and another product of instructional.

\section{References}

i. Johnson, E.B. 2002. Contextual Teaching and Learning. California: Corwin Press.Inc

ii. Lee, Jinhyun and Jang, Seonyoung. 2014. A Methodological Framework for Instructional Design Model Development: Critical Dimensions and Synthesized Procedures. Korean Education Technology Research Development, 62: 743-765.

iii. Richey, Rita.and C, Klein, J. D.2007. Design and Development Research. New Jersey: Lawrence Erlbaum Associates, Inc.

iv. Rusdi, M. 2018. Penelitian dan Pengembangan Kependidikan: Konsep, Prosedur dan Sintesis Pengetahuan Baru. Depok: PT RjaGrafindo Persada. 